\title{
Plant grafting: new mechanisms, evolutionary implications
}

\section{Eliezer E. Goldschmidt*}

The Robert H. Smith Institute of Plant Sciences and Genetics in Agriculture, Faculty of Agriculture, Food and Environment, The Hebrew University of Jerusalem, Rehovot, Israel

\section{Edited by:}

Julia Kehr, University of Hamburg,

Germany

\section{Reviewed by:}

Woei-Jiun Guo, National Cheng Kung University, Taiwan

Friedrich Kragler, Max Planck Institute for Molecular Plant Physiology, Germany

\section{${ }^{*}$ Correspondence:}

Eliezer E. Goldschmidt, The Robert H. Smith Institute of Plant Sciences and Genetics in Agriculture, Faculty of Agriculture, Food and Environment, The Hebrew University of Jerusalem, P.O. Box 12, Rehovot 76100, Israel e-mail: eli.goldsmit@mail.huji.ac.il
Grafting, an old plant propagation practice, is still widely used with fruit trees and in recent decades also with vegetables. Taxonomic proximity is a general prerequisite for successful graft-take and long-term survival of the grafted, composite plant. However, the mechanisms underlying interspecific graft incompatibility are as yet insufficiently understood. Hormonal signals, auxin in particular, are believed to play an important role in the wound healing and vascular regeneration within the graft union zone. Incomplete and convoluted vascular connections impede the vital upward and downward whole plant transfer routes. Longdistance protein, mRNA and small RNA graft-transmissible signals currently emerge as novel mechanisms which regulate nutritional and developmental root/top relations and may play a pivotal role in grafting physiology. Grafting also has significant pathogenic projections. On one hand, stock to scion mechanical contact enables the spread of diseases, even without a complete graft union. But, on the other hand, grafting onto resistant rootstocks serves as a principal tool in the management of fruit tree plagues and vegetable soil-borne diseases. The 'graft hybrid' historic controversy has not yet been resolved. Recent evidence suggests that epigenetic modification of DNA-methylation patterns may account for certain graft-transformation phenomena. Root grafting is a wide spread natural phenomenon; both intraspecific and interspecific root grafts have been recorded. Root grafts have an evolutionary role in the survival of storm-hit forest stands as well as in the spread of devastating diseases. A more fundamental evolutionary role is hinted by recent findings that demonstrate plastid and nuclear genome transfer between distinct Nicotiana species in the graft union zone, within a tissue culture system. This has led to the formation of alloploid cells that, under laboratory conditions, gave rise to a novel, alloploid Nicotiana species, indicating that natural grafts may play a role in plant speciation, under certain circumstances.

Keywords: epigenetics, genome transfer, graft hybrids, incompatibility, long-distance signals, microRNA

\section{INTRODUCTION}

Grafting is an ancient, vegetative, asexual plant propagation technique. It is accomplished most commonly by connecting two plant segments, the shoot piece known as 'scion' and the root piece called 'rootstock'(stock). A broad range of classical grafting techniques can be found in Garner (2013); recent seedling micrografting protocols have been summarized by Turnbull (2010). Grafting has been practiced for many centuries with perennials - mainly fruit trees but also some forest trees and ornamentals - but, as of the early 20th century also with vegetable crops, mainly Cucurbitae and Solanaceae species. Thus, the majority of recent grafting research concerns physiological and pathological aspects of vegetable grafting. Grafting also plays an important role in various types of physiological investigations (Lifshitz et al., 2006; Omid et al., 2007; Wang, 2011), in particular in classical studies on the movement of the floral stimulus (Zeevaart, 2006). An overview of the current state of the art can be obtained from several recent reviews, each emphasizing a slightly different aspect (Pina and Errea, 2005; Aloni et al., 2010; Harada, 2010; Louws et al., 2010; Martinez-Ballesta et al., 2010; Koepke and Dhingra, 2013). The history of grafting has been described in detail by Mudge et al. (2009). Attempts to provide adequate explanations for the immediate and long-term effects of grafting have been made for generations but, according to a recent review, this plant propagation practice is still shrouded in mystery (Koepke and Dhingra, 2013). Undoubtedly, the use of a large number of diverse plant species in grafting studies has slowed down progress in this research area. The recent introduction of the Arabidopsis model into grafting research (Turnbull et al., 2002; Turnbull, 2010) has opened the way for more targeted, advanced grafting research. Thus, the purpose of the present, concise update is threefold: (a) To point out a few major lacunas in our understanding of grafting processes. (b) To introduce some novel, emerging graft physiology mechanisms. (c) To discuss recent evidence that suggests a role for natural grafting in plant evolution.

\section{GRAFT COMPATIBILITY AND INCOMPATIBILITY}

There is no precise definition of 'graft compatibility'; it generally means establishment of a successful graft union as well as extended survival and proper functioning of the composite, grafted plant. Taxonomic affinity is a prerequisite for graft compatibility. Homografts (= autografts) are presumably always compatible. In heterografts, broadly speaking, intraspecific grafts (= rootstock and scion belonging to the same botanical species) 
are nearly always compatible, interspecific grafts (= rootstock and scion belonging to different species of the same genus) are usually compatible, intrafamilial grafts are rarely compatible, and interfamilial grafts are essentially always incompatible (Mudge et al., 2009). Examination of heterografts compatibility should include homograft controls (Olmstead et al., 2006; Flaishman et al., 2008; Kawaguchi et al., 2008), a requirement not always fulfilled (Guan et al., 2012). Even in homografts, where rootstock and scion share the same genetic background, certain grafting effects are evident. Differences in rootstock and scion age and juvenility markedly affect their microRNA (miRNA) expression patterns and reproductive development (Poethig, 2009; Wang et al., 2011; Tzarfati etal., 2013). In sweet pepper (Capsicum annuum L.), old-stage homografts (58 days old plants) had slower graft-take than young-stage (34 days) homografts. Old-stage grafts had a lower percentage of xylem connections and seemed to suffer from drought stress (Johkan et al., 2009). The time needed for the establishment of a functional graft union is considerably shorter in herbaceous plants than in trees. In the recently introduced Arabidopsis micrograft system 7-12 days are required (Turnbull, 2010) but Yin et al. (2012) achieved functional vasculature in Arabidopsis within 3 days after grafting. Several months are commonly required for completion of a functional union in tree grafts (e.g., Olmstead et al., 2006).

Graft incompatibility may be defined as failure to form a successful graft union. Yet, despite innumerous follow-ups of graftage in various types of plants, the reasons for graft incompatibility are still vague. Initial healing of the graft union does not in itself ensure long-term compatibility. In cucurbits, apparently successful grafts proved incompatible 25 days after grafting (Edelstein et al., 2004; Aloni et al., 2008). In certain tree stock/scion combinations incompatibility may appear only after several years. (Mosse, 1962; Wutscher, 1979; Tuttle and Gotlieb, 1985). Although incompatibility is not a measurable quantitative trait, various degrees of incompatibility may be discerned, from mild interference with the normal development of the composite plant to mortality of the stock, scion or both.

As already pointed out by Moore (1984), as yet there is no evidence for a specific biochemical-immunological recognition/ rejection mechanism between the graft components. This is in contrast to pollination incompatibility, where specific mechanisms have been identified (Kao and Huang, 1994; Takayama and Isogai, 2005; De Franceschi et al., 2012). Yet, heterograft incompatibility clearly increases with genetic distance (Schöning and Kollmann, 1997; Flaishman et al., 2008), indicating some kind of physiological rejection. On the other hand, incompatibility occurs even among related genera of the same family in a rather unpredictable fashion. Thus, within the Solanaceae, reciprocal grafts of tomato (Solanum lycopersicum L.) and pepper were considered severely incompatible, whereas tomato and eggplant (Solanum melongena L.) only moderately so, in comparison with compatible tomato homografts (Kawaguchi et al., 2008). Considerable variation in degree of compatibility was evident among grafts of melon (Cucumis melo L.) onto 22 Cucurbitae rootstocks (Edelstein et al., 2004) and among other Cucurbitae species (Lee and Oda, 2003) and among chestnut (Castanea) species (Huang et al., 1994). In citrus trees, visual inspection of trunks at the graft union was believed to reflect the degree of compatibility (Figure 1, reproduced from Webber, 1948), although some graft combinations proved to be successful despite the unsmooth graft union (Wutscher, 1979). Anatomical follow-ups of heterograft unions invariably disclose mild to severe interferences with the formation of a fully functional stock/scion continuum. Changes in vascular anatomy were evident in grafts of apple (Malus domestica Borkh. and sweet cherry (Prunus avium L.) onto dwarfing rootstocks (Soumelidou et al., 1994; Olmstead et al., 2006) and even in compatible graft unions among Pinus species (Darikova et al., 2013). A commonly observed disturbance is a convolution of the vascular elements orientation (Soumelidou et al., 1994; Flaishman et al., 2008; Kawaguchi et al., 2008). Soumelidou et al. (1994) proposed that wound-induced changes in the normal flow of endogenous auxin, which plays a key role in vascular differentiation (Aloni, 1995; Cano-Delgado et al., 2010), might be responsible for this distortion. This hypothesis is supported by the recent study of Yin et al. (2012) who demonstrated the involvement of auxin in early stages of graft union formation. The oxidative stress symptoms reported by Aloni et al. (2008) appear only at a considerably later stage and may represent a belated response to the auxin imbalance.

\section{ROOT-TOP INTERACTIONS}

Major grafting effects are readily comprehensible if viewed in the broader context of root-top relations. Thus, dwarfing

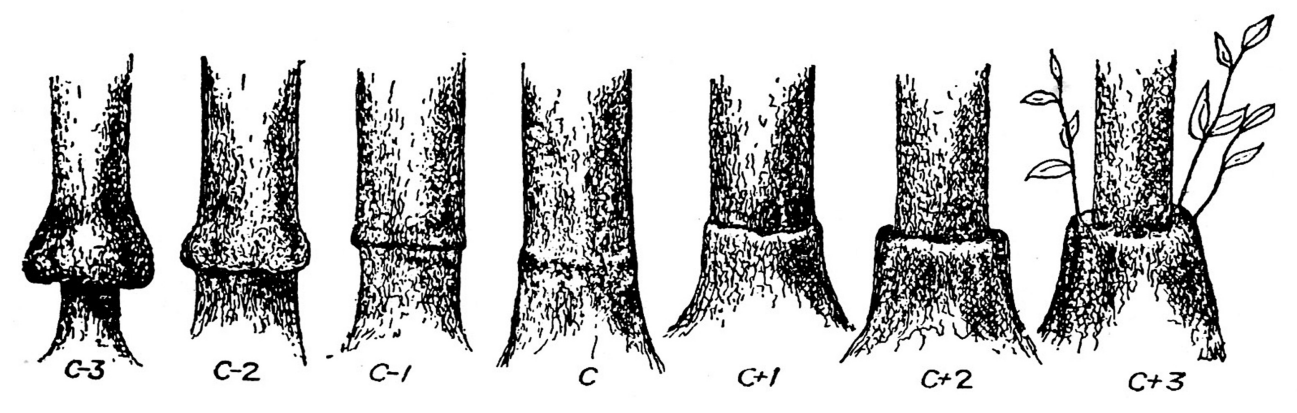

FIGURE 1 | A range of citrus graft union shapes, presumably indicating rootstock-scion compatibility (reproduced from Webber, 1948; with permission). 
rootstock effects (Webster, 2002) are not surprising once the well-documented Bonsai culture and root restriction effects are kept in mind (Erez et al., 1992; Ismail and Davies, 1998). By the same token, the invigorating effect of strong, expansive Cucurbitae rootstocks on their scions (Blestos, 2005; Martinez-Ballesta et al., 2010) might be anticipated, although the precise physiological mechanisms involved need clarification. The rather complex natural root-top relationship is further complicated in the composite, grafted plant, which undergoes a drastic wounding/healing operation, followed by life-long interactions between different genomes.

Most long-term compatibility studies have been conducted with fruit trees. Xylem graft union anatomy determines the hydraulic root-top conductivity in apple, thereby affecting the growth potential of rootstock/scion combinations (Atkinson et al., 2003). Phloem graft union irregularities appear to be a major source of long-term incompatibility. The pioneering studies of Gur et al. (1968) demonstrated a gradual build-up of biochemical poisoning reaction between pear (Pyrus communis L.) scions and quince (Cydonia oblonga Mill.) rootstocks. Prunasin, a cyanogenic glucoside, rises from the quince rootstock into the pear scion, where it is catabolized enzymatically by pear glycosidase to liberate cyanide at the graft interface. Cyanide 'poisons' the graft union tissues, causing cellular necrosis at the graft interface, leading to severe incompatibility (Gur et al., 1968). However, further studies with peach (Prunus persica L. Batsch) grafted on myrobalan plum (Prunus cerasifera L. Ehrh) suggested a more general poisoning mechanism, due to progressive impairment of the phloem carbohydrate transport and accumulation of starch above the graft union (Breen and Muraoka, 1975; Moing et al., 1990). Gradual starch accumulation is indeed a symptom of serious interference with nutrient metabolism and root starvation (Moing and Gaudillere, 1992). These phenomena resemble the damage often caused by girdling ( = removal of a ring of bark from the trunk or branch of a tree; Li et al., 2003; Goren et al., 2004). Rootstock-scion interactions persist throughout the life of the composite plant, even where satisfactory graft compatibility has been achieved. The upward supply of water and mineral nutrients as well as the downward flow of photosynthates are modified and so is the root-top interchange of hormonal signals (Cutting and Lyne, 1993; Aloni et al., 2010). These mechanisms may account for many of the well-known grafting effects.

\section{PROTEIN AND RNA SIGNALS}

Long-distance phloem transport of proteins and RNAs and their potential role in inter-organ signaling has become a major research domain in recent years (Golecki et al., 1998; Lough and Lucas, 2006; Omid et al., 2007; Kalantidis et al., 2008; Harada, 2010; Kehr and Buhtz, 2013; Spiegelman et al., 2013). Trans-graft transmission of gene silencing in tobacco (Nicotiana tabacum L.), which presumably involves some kind of mobile RNA, was one of the pioneering findings in this area (Palauqui et al., 1997). A number of small RNAs (Buhtz etal., 2008) and even some mRNA (Haywood et al., 2005; Omid et al., 2007; Spiegelman et al., 2013) have been identified in phloem saps. Root-to-top as well as top-to root graft transmissible signals have been convincingly demonstrated (Brosnan et al., 2007; Molnar et al., 2010). The involvement of miRNAs in grafting effects has been demonstrated recently by Tzarfati et al. (2013). Reduction of juvenility is one of the most conspicuous effects of grafting in trees (Wareing, 1959; Mudge et al., 2009). The juvenile-to-adult transition in trees (Wang et al., 2011) as well as in annuals (Poethig, 2009) is mediated by a marked decline in the expression of miR156. Both heterograft and homograft citrus scions had reduced miR156 (and the related miR157) expression rates as compared with non-grafted control seedlings, suggesting a role for miRNAs in primary grafting effects (Tzarfati et al., 2013). Changes in the expression of specific miRNAs have recently been implied in heritable chimeras of grafted Brassica $s p$. (Li et al., 2013); however, only a few miRNAs have been shown to be graft-transmissible so far (Buhtz et al., 2010; Bhogale et al., 2014).

There is no obvious reason why a viable, physiologically functional graft union should interfere with regular, long-distance vascular transport. However, the occurrence of a compound which supposedly originated in one organ (e.g., apical meristem), in a distant organ (e.g., roots), does not in itself prove its vascular transport, since this compound could also be synthesized in the presumably recipient organ. Therefore, grafting of genetically distinct mutants/transgenes is still being used as a principal means to distinguish between the site of biogenesis and the recipient organs (Buhtz et al., 2010; Molnar et al., 2010; Turnbull, 2010). Roots of grafted Arabidopsis contained specific small RNAs that originated in the apical, source organs, although they were less abundant than in the source tissue by three orders of magnitude (Molnar et al., 2010). Furthermore, the identification of a mobile macromolecule does not indicate in itself a physiological role. The complexities of this area have been discussed by Melnyk et al. (2011).

Notwithstanding, physiologically meaningful protein and RNA long-distance signaling has been convincingly demonstrated in several plant systems. The identification of the FT protein as a major, graft-transmissible component of the long-sought universal florigen is a highly significant achievement (Corbesier et al., 2007; Zeevaart, 2008). The role of phloem mobile miRNAs in the systemic regulation of several key mineral nutrients appears to be a principal mechanism (Buhtz et al., 2010; Kehr, 2013). The regulation of potato (Solanum tuberosum L.) tuberization by the graft transmissible miR156 is another recently studied case (Bhogale et al., 2014). The regulatory role of graft transmissible mRNA has now been clearly demonstrated with the Gibberellic Acid Insensitive (GAI) mRNA, including the anticipated changes in plant phenotype (Xu et al., 2013b). Thus, we have by now ample evidence for the regulatory role of both protein and several types of RNA as long-distance, graft-transmissible signals, and further discoveries in this area can be expected.

\section{PATHOLOGICAL ASPECTS}

The role of grafting in plant disease is a "double-edged sword." On one hand, grafting played a pivotal role in the spread of many important plant diseases. But, on the other hand, grafting has become the principal means in overcoming most hazardous plant epidemics and pests.

Plant pathogens spread in tree communities (forests and plantations) through a variety of tracks, including natural, 
underground root grafts. This avenue of disease transmission has been underestimated (Epstein, 1978), just as root grafting in general has been somewhat neglected (Lev-Yadun, 2011). Its significance became evident with the burst of oak wilt and Dutch elm fungal disease epidemics during the midst of the 20th century (Epstein, 1978). Also viral diseases are transmitted by root grafting (Fulton, 1966; Epstein, 1978). The frequency of intraspecific and interspecific root grafts in wild forest stands has been examined in just a few cases (Blaedow and Juzwik, 2010). Generally, there are considerable differences in the actual significance of disease spread by root grafts between crops and habitats.

Parasitic plants such as mistletoes (= parasitic plants in the order Santalales) and dodder (Cuscuta sp.) transmit pathogens very efficiently, even among intergeneric and interfamilial plant species (Birschwilks et al., 2006; Mudge et al., 2009; Mikona and Jelkmann, 2010; LeBlanc et al., 2012). Dodder is often used in experimental studies as a bridging vehicle between distant, graft incompatible plant species. Thus, the parasitic, invasive disease transmission mechanism goes beyond the phylogenetic graft compatibility barriers and these seemingly similar pathogen spread pathways cannot be simply equated (LeBlanc et al., 2012).

Grafting of virus infected plant material is another, dangerous way of disease transmission. Graft-transmission of pathogens does not require a compatible, physiologically functional graft union. Even mechanical contact, such as using a contaminated grafting device, can spread viral and bacterial diseases (Barbosa et al., 2005; Bausher, 2013). Interfamilial grafts of citrus on avocado (Persea americana Mill.) transferred a citrus viroid to avocado; the grafted citrus budwood remained viable for almost a year without forming a true graft union (Hadas et al., 1992). Periwinkle (Catharanthus sp.) seems to be unique in its ability to form distant interspecific grafts. The apple proliferation phytoplasma disease was transmitted from infected apple scions to periwinkle rootstocks (Aldaghi et al., 2007). There is no evidence, however, that such periwinkle grafts form a true, functional graft union.

The role of grafting in the management and control of a broad array of plant pests is nowadays a high priority topic; grafting of Cucurbitae and Solanaceae vegetables to control soil-borne diseases is widely practiced (King et al., 2008; Louws et al., 2010). The beginnings are, however, considerably older. Grafting of citrus onto sweet orange to combat the Phytophthora foot rot (Wutscher, 1979), and grafting of Vitis vinifera onto American (Vitis labrusca and other species) rootstocks to overcome the Phylloxera grapevine plague (Mudge et al., 2009) were adopted in the 19th century. The 20th century struggle of the citrus industry with the Citrus tristeza virus (Closterovirus) and other virus-like diseases exploited every possible graft combination (Bar-Joseph et al., 1989). The selection of suitable fruit tree rootstock/scion combinations is dominated by disease resistance considerations even today; soil and climate adaptation also affect the preferable stock/scion selection.

Nevertheless, most recent research focuses on vegetable grafting. Superimposed on the natural plant disease resistance (Hammond-Kosack and Jones, 1997) comes once more the complexity of the composite, grafted plant. The diverse mechanisms involved in disease resistance of grafted vegetables have been reviewed by Guan et al. (2012). These range from genetic nonhost resistance and rootstock vigor effects to rootstock-induced systemic acquired resistance, which involves salicylate (Conrath, 2006; Park et al., 2008), jasmonate (Schilmiller and Howe, 2005), and other plant hormone signals (Bari and Jones, 2009; Aloni et al., 2010).

Long-distance protein and RNA signals (see previous section) also seem to play a role in rootstock-induced disease resistance. Polygalacturonase-inhibiting proteins (PGIPs) are plant cell proteins that specifically inhibit the cell wall degrading endopolygalacturonases of plant pathogens (Aguero et al., 2005). Leaf extracts and xylem exudates from grapevine rootstocks transformed to express the pear fruit PGIP-encoding gene ( $p P G I P)$ had PGIP activity. PGIP was detected in xylem exudates of untransformed grapevine scions grafted onto transgenic rootstocks expressing $P P G I P$, indicating that the PGIP protein is grafttransmissible. Such scions revealed improved tolerance toward grapevine diseases caused by Xylella fastidiosa and Botrytis cinerea (Aguero etal., 2005). Following these results, Haroldsen et al. (2012) suggested that cultivars genetically engineered to express disease controlling, graft-transmissible proteins and RNAs, could be used as rootstocks for disease susceptible scion cultivars. Grafting genetically engineered rootstocks with non-transformed fruit tree scions would presumably result in disease-resistant cultivars bearing fruits which are not genetically modified, a desirable combination (Haroldsen et al., 2012). This idea undoubtedly merits further research.

\section{GRAFT TRANSFORMATION}

Of all grafting issues, the least understood and most controversial is the 'graft hybrid' concept. According to this concept grafting may involve stock to scion transfer of genetic material (= graft transformation), leading to heritable changes in the scion. The scion which has acquired certain heritable traits from the rootstock is regarded as a 'graft hybrid.' However, graft transformations occur only under 'Mentor grafting' conditions, which presumably enforce the transfer of genetic material from stock to scion (Figure 2).

In 'Mentor grafting,' young seedlings shoots serving as 'scions' are grafted onto mature, flowering plants used as 'stocks.' To make sure that the scions fully depend on the stock for the supply of nutrients, leaves of the scions (except for two or three leaves at the top) are removed throughout the experiment. Stock fruits are also removed in attempt to maximize flow of substances from the stock to the scion (Ohta, 1991). Interestingly, the 'Mentor grafting' technique is the same as that used in classical flowering research, where removal of leaves from the scion was expected to promote stock to scion movement of the floral stimulus (Lang, 1965).

The graft hybrid concept, which was developed and demonstrated by the Soviet horticulturist Michurin (1949), appeared to be in contrast with Mendelian genetics and was rejected (and almost forgotten) by Western scientists who opposed and distrusted the Soviet biology led by Lysenko. Several published studies (and most probably many unpublished) could not confirm the appearance of graft hybrids (Stubbe, 1954; Bohme, 1957; Topoleski and Janick, 1963; Menda et al., 2006). Yet, reports supporting the 


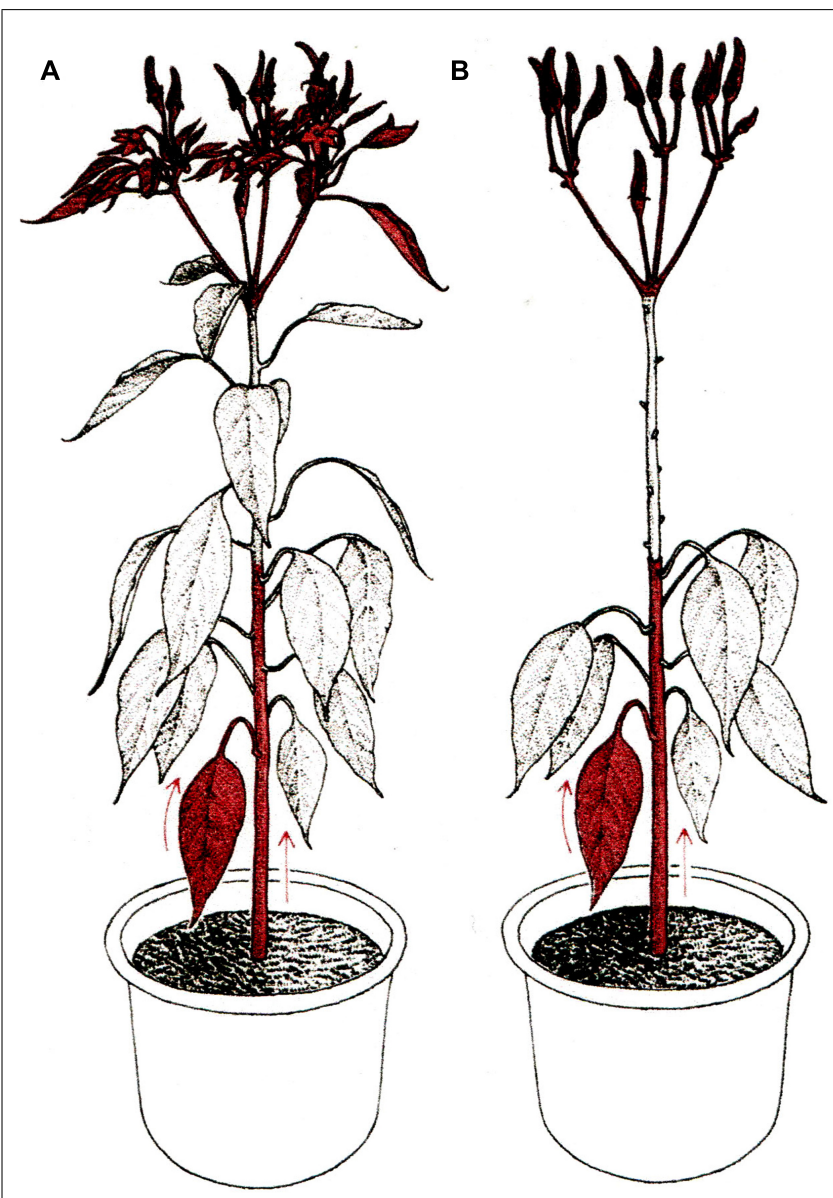

FIGURE 2 | Mentor grafting. (A) Non-graft normal plant as control. (B) Mentor graft; scion leaves were removed in order to facilitate chromatin translocation from rootstock leaves and stems to the primordial organs of the scion. Arrows indicate the direction of chromatin translocation (reproduced from Ohta, 1991; with permission).

occurrence of graft transformations appeared from time to time (Frankel, 1956), and increasingly so in recent years (Li et al., 2013; Tsaballa et al., 2013; Wu etal., 2013; Zhou etal., 2013). Proponents of the graft hybrid concept reviewed the supporting evidence and called for reassessment of the graft transformation hypothesis that has been neglected for several decades (Liu, 2006; Liu et al., 2010).

Within the 'graft hybrid' supportive evidence some specific characteristics can be defined. (a) The frequency of the appearance of variant plants is highly variable, sometimes below 1\% (Ohta, 1991). Thus, the argument that 'no variants were found' must be based on a very large number of replicate grafts. Indeed, some of the 'negative' reports used several thousands of grafts (Stubbe, 1954). (b) The graft hybrid experimental evidence rests almost exclusively on intra- and interspecific grafting of Solanaceae, in particular pepper (Ohta, 1991; Taller et al., 1998; Tsaballa et al., 2013), which is somehow more amenable than other plant species to rootstock-induced scion transformation. (c) The alleged rootstock to scion transmission of genetic material is the most mysterious part of it all. The initial belief of Michurin (1949) that genes can move between rootstock and scion has been refined by Ohta (1991) who presented histological evidence that masses of chromatin are moving via the vascular system from the older rootstock across the graft union to the apical primordia or flower buds of the younger, mentor-grafted scion. The model of amplified plasmodesmatal macromolecular transport toward apical meristems (Ueki and Citovski, 2005) has been cited in this context (Liu, 2006) but no further evidence in support of this mechanism has been presented.

In their review, Mudge et al. (2009) indicated that the emerging concept of graft-transmissible gene silencing signals may hold the key for a new approach to the graft transformation riddle. Recent research further extends this view in conjunction with probable involvement of epigenetic inheritance mechanisms.

Epigenetics refers to reversible heritable changes in genome function that occur without a change in the DNA sequence and may have morphological, physiological, and ecological consequences (Rapp and Wendel, 2005; Fossey, 2009). Changes in DNA methylation are presumably among the principal, ubiquitous epigenetic mechanisms (Rapp and Wendel, 2005) although their heritability requires further elucidation (Paszkowski and Grossniklaus, 2011). DNA methylation during plant gametogenesis, in particular, appears to involve epigenetic, heritable changes (Takeda and Paszkowski, 2006; Calcaro et al., 2012). Plant DNA methylation has been shown to be regulated by siRNAs; 'siRNA-mediated epigenetic modification' is currently an acceptable term (Xu et al., 2013a).

As already discussed, graft-transmissible RNA gene silencing signals have been demonstrated in both the upward (Brosnan et al., 2007) and the downward direction (Molnar et al., 2010). Changes in DNA methylation in the recipient organs have been detected; these changes are regarded as epigenetic modifications (Molnar et al., 2010). Partially heritable, locus-specific alteration of DNA methylation patterns have recently been found in scions of interspecific grafts of Solanaceae (Wu et al., 2013). Wu et al. (2013) think that their research paves the way for resolution of the graft hybrid controversy. However, further, rigorous research is desperately needed, in order to unequivocally elucidate the graft hybrid graft transformation issues.

\section{EVOLUTIONARY SIGNIFICANCE}

Grafting is a natural phenomenon, wide spread between roots of the same tree, neighbor trees of the same species or even, although less frequently, among trees belonging to different species (= interspecific grafting). Root grafting could be induced artificially between potted Picea abies trees; a pair of compressed roots fused and formed a complete union within several months (Fischer et al., 1960). Natural grafting is not confined to roots; intra- and interspecific grafts among tree branches have been described (Mudge et al., 2009; Stegemann et al., 2012). Although anatomical evidence is scarce (Rao, 1966), it may be assumed that mutual pressure between two adjacent roots builds-up as they increase in diameter, since the surrounding soil precludes much lateral displacement of the two roots. With increasing pressure the bark of each in contact with the other wears away, bringing their cambia in contact, leading eventually to a functional graft union. Most aerial grafts occur when a branch from one tree is 
"caught" in the forked branch of another tree, which is analogous to the compression between adjacent roots (K. W. Mudge, personal communication, with permission).

Assessment of the evolutionary significance of grafting involves discussion at two levels: its benefits for plant survival and its potential role in the formation of new species. The plausible ecological benefits of root grafting have been discussed by Lev-Yadun (2011). The existence of underground graft contacts turns the individual tree into member of a cooperative community which may support each other in a variety of physical, nutritional and reproductive ways (Eis, 1972). Bormann (1966) observed that stumps sometimes persist and continue to grow for years or even decades, when root-grafted to adjacent trees but not when occurring singly, suggesting that nutrients arriving via root grafts from standing neighbor trees are responsible for the persistence of the stump. Trees that lost their crowns in a storm etc. may survive and resume above ground growth and reproduction owing to their root graft cooperation (Mudge et al., 2009; Lev-Yadun, 2011). On the other hand, as already mentioned in a previous section, there is a very real risk of pathogen transmission via natural root grafts, including fungal, bacterial (Lopes et al., 2009), viral and mycoplasmal diseases (Epstein, 1978). In as much as agriculture is nowadays considered a component of the evolutionary arena (Ross-Ibarra et al., 2007; Thrall et al., 2010), grafting also plays a critical role in the survival of thousands of manselected plant genotypes which are propagated only by grafting and have never existed in natural habitats (Janick, 2005; Goldschmidt, 2013).

Addressing the significance of grafting as a potential evolutionary mechanism must take into account the ancient belief that grafting may give rise to new plant species (Mudge et al., 2009). The 'graft hybrid' concept discussed in the preceding section is also related to this belief. Some of the novel species records may be attributed to graft chimeras, which are not true hybrids, but are inheritable (Swingle, 1927; Mudge et al., 2009). Adventitious buds may develop from the graft junction, and the lateral, developing chimeral shoots may retain a stable, heritable intermediate phenotype. Lateral shoots from graft junction wounds occur frequently, and a considerable percentage of those are stable chimeras (Kaddoura and Mantell, 1991).

Recent research has brought us much closer to a potentially real evolutionary grafting mechanism. In their early report Stegemann and Bock (2009) demonstrated exchange of plastid genome material between stock and scion cells in interspecific graft junction zones, later shown to consist of entire chloroplast genome transfer between distinct Nicotiana species (Stegemann et al., 2012). Interestingly, in their initial report Stegemann and Bock (2009) state that their data.

\footnotetext{
“... do not lend support to the tenet of Lysenkoism that'graft hybridization' would be analogous to sexual hybridization. Instead, our finding that gene transfer is restricted to the contact zone between scion and stock indicates that the changes can become heritable only via lateral shoot formation from the graft site."
}

However, in a more recent report (Fuentes et al., 2014) Bock and his team come up with a bolder title; "Horizontal genome transfer as an asexual path to the formation of new species." Tissue cultured plants were grafted, and the tissue very close to the graft junction (some millimeters from the junction) was maintained and screened further in tissue cultures. The results show that entire nuclear genomes were transferred between plant cells in the graft junction zone, leading to the formation of novel, alloploid plant cells, and such events occurred at a considerable frequency. Plants recovered from these cells are real graft hybrids. A fertile, stable hybrid between herbaceous and woody Nicotiana species was thus obtained, tentatively named Nicotiana tabauca. Still, natural evolutionary formation of new species via this pathway would depend upon natural graft formation and emergence of adventitious lateral shoots, as previously discussed.

The hypothetical possibility of cell fusion graft hybrids has already been mentioned by Swingle (1927; Figure 12). Genome combinations have indeed been achieved in artificial protoplast fusion systems, and interspecific hybrid plants were obtained (Evans etal., 1980; Shepard et al., 1983). However, the recent findings of Bock's team raise the exciting option that natural grafting may have played an active evolutionary role in plant speciation. The results obtained with Nicotiana under tissue culture conditions require further confirmation with other plants in natural settings (Hare, 2014). It is difficult at the present time to estimate the actual contribution of this asexual path to plant evolution. Although seemingly dependent upon a rare sequence of events, this evolutionary niche could have been exploited as a plant survival bypass under extreme selective pressure conditions.

\section{CONCLUDING REMARKS}

While the technology of grafting has advanced tremendously, the long-term survival of grafted, composite plants is still somewhat unpredictable. The complexity of stock/scion interactions attains a new dimension when pathogenic agents enter the scenery. More enigmatic are the graft hybrid conundrum and the broader evolutionary significance of grafting. The extensive horticultural grafting research has not usually addressed these basic questions. The recently adopted Arabidopsis model has opened the way for meticulous, in-depth grafting research. The currently available molecular tools are expected to advance our understanding and eventually resolve the long standing grafting mysteries.

\section{ACKNOWLEDGMENTS}

The author acknowledges the valuable comments on the manuscript by Arie Altman (The Hebrew University of Jerusalem) and Moshe Bar-Joseph (Volcani Center, Agricultural Research Organization). The help of Amram Ashri (The Hebrew University of Jerusalem) in revision and final refinement of the manuscript is gratefully appreciated.

\section{REFERENCES}

Aguero, C. B., Uratsu, S. L., Greve, C., Powell, A. L. T., Labavitch, J. M., Meredith, C. P., et al. (2005). Evaluation of tolerance to Pierce's disease and Botrytis in transgenic plants of Vitis vinifera L. expressing the pear PGIP gene. Mol. Plant Pathol. 6, 43-51. doi: 10.1111/j.1364-3703.2004.00262.x

Aldaghi, M., Massart, S., Steyer, S., Lateur, M., and Jijakli, M. H. (2007). Study on diverse grafting techniques for their capability in rapid and efficient transmission of apple proliferation disease to different host plants. Bull. Insectol. 60, 381-382.

Aloni, B., Cohen, R., Karni, L., Aktas, H., and Edelstein, M. (2010). Hormonal signaling in rootstock-scion interactions. Sci. Hortic. 127, 119-126. doi: 10.1016/j.scienta.2010.09.003 
Aloni, B., Karni, L., Deventureo, G., Levin, Z., Cohen, R., Katzir, N., et al. (2008). Physiological and biochemical changes at the rootstock-scion interface in graft combinations between Cucurbita rootstocks and a melon scion. J. Hortic. Sci. Biotechnol. 83, 777-783.

Aloni, R. (1995). “The induction of vascular tissues by auxin and cytokinin," in Plant Hormones, ed. P. J. Davies (Dordrecht: Kluwer Academic Publishers), 531-546.

Atkinson, C. J., Else, M. A., Taylor, L., and Dover, C. J. (2003). Root and stem hydraulic conductivity as determinants of growth potential in grafted trees of apple (Malus pumila Mill.) J. Exp. Bot. 54, 1221-1229. doi: 10.1093/jxb/ erg132

Barbosa, C. J., Pina, J. A., Pérez-Panadés, J., Bernad, L., Serra, P., Navarro, L., and Duran-Vila, N. (2005). Mechanical transmission of citrus viroids. Plant Dis. 89, 749-754. doi: 10.1094/PD-89-0749

Bar-Joseph, M., Marcus, R., and Lee, R. F. (1989). The continuous challenge of citrus tristeza virus control. Annu. Rev. Phytopathol. 27, 291-316. doi 10.1146/annurev.py.27.090189.001451

Bari, R., and Jones, J. D. G. (2009). Role of plant hormones in plant defense responses. Plant Mol. Biol. 69, 473-488. doi: 10.1007/s11103-008-9435-0

Bausher, M. G. (2013). Serial transmission of plant viruses by cutting implements during grafting. HortScience 48, 37-39.

Bhogale, S., Mahajan, A. S., Natarajan, B., Rajabhoj, M., Thulasiram, H. V., and Banerjee, A. K. (2014). MicroRNA156: a potential graft-transmissible microRNA that modulates plant architecture and tuberization in Solanum tuberosum ssp. andigena. Plant Physiol. 164, 1011-1027. doi: 10.1104/pp.113.230714

Birschwilks, M., Haupt, S., Holfus, D., and Neumann, S. (2006). Transfer of phloemmobile substances from the host plants to the holoparasite Cuscuta sp. J. Exp. Bot 57, 911-921. doi: 10.1093/jxb/erj076

Blaedow, R. A., and Juzwik, J. (2010). Spatial and temporal distribution of Ceratocystis fagacearum in roots and root grafts of oak wilt affected red oaks. Arboric Urban For. 36, 28-34.

Blestos, F. A. (2005). Use of grafting and calcium cyanamide as alternatives to methyl bromide soil fumigation and their effects on growth, yield, quality and fusarium wilt control in melon. J. Phytopathol. 153, 155-161. doi: 10.1111/j.14390434.2005.00945.x

Bohme, H. (1957). Weitereuntersuchungen zum problem der genetischenbedeutung von pfropfungen zwischen genotypisch verschiedenen pflanzen. Z. f. Pflanzenz $38,37-50$.

Bormann, F. H. (1966). The structure, function, and ecological significance of root grafts in Pinus strobus L. Ecol. Monogr. 36, 1-26. doi: 10.2307/1948486

Breen, P. J., and Muraoka, T. (1975). Seasonal nutrient levels and peach graft incompatibility. J. Am. Soc. Hortic. Sci. 100, 339-342.

Brosnan, C. A., Mitter, N., Christie, M., Smith, N. A., Waterhouse, P. M., and Carroll, B. J. (2007). Nuclear gene silencing directs reception of long-distance mRNA silencing in Arabidopsis. Proc. Natl. Acad. Sci. U.S.A. 104, 14741-14746. doi: 10.1073/pnas.0706701104

Buhtz, A., Pieritz, J., Springer, F., and Kehr, J. (2010). Phloem small RNAs, nutrient stress responses, and systemic mobility. BMC Plant Biol. 10:64. doi: 10.1186/14712229-10-64

Buhtz, A., Springer, F., Chappell, L., Baulcombe, D. C., and Kehr, J. (2008). Identification and characterization of small RNAs from the phloem of Brassica napus. Plant J. 53, 739-749. doi: 10.1111/j.1365-313X.2007.03368.x

Calcaro, J. P., Borges, F., Donoghue, M. T. A., Van Ex, F., Jullien, P. E., Lopes, T., et al. (2012). Reprogramming of DNA methylation in pollen guides epigenetic inheritance via small RNA. Cell 151, 194-205. doi: 10.1016/j.cell.2012.09.001

Cano-Delgado, A., Lee, J. Y., and Demura, T. (2010). Regulatory mechanisms for specification and patterning of plant vascular tissues. Annu. Rev. Cell Dev. Biol. 26, 605-637. doi: 10.1146/annurev-cellbio-100109-104107

Conrath, U. (2006). Systemic acquired resistance. Plant Signal. Behav. 1, 179-184. doi: $10.4161 /$ psb.1.4.3221

Corbesier, L., Vincent, C., Jang, S., Fornara, F., Fan, Q., Searle, I., et al. (2007). FT protein movement contributes to long-distance signaling in floral induction of Arabidopsis. Science 316, 1030-1033. doi: 10.1126/science. 1141752

Cutting, J. G. M., and Lyne, M. C. (1993). Girdling and the reduction in shoo xylem sap concentrations of cytokinins and gibberellins in peach. J. Hortic. Sci. 68, 619-626.

Darikova, Y. A., Vaganov, E. A., Kuznetsova, G. V., and Grachev, A. M. (2013) Changes in anatomical structure of tree rings of the rootstock and scion in het erografts of Siberian pine. Trees 27, 1621-1631. doi: 10.1007/s00468-013-0909-6
De Franceschi, P., Dondini, L., and Sanzol, J. (2012). Molecular bases and evolutionary dynamics of self-incompatibility in the Pyrinae (Rosaceae). J. Exp. Bot. 63, 4015-4032. doi: 10.1093/jxb/ers108

Edelstein, M., Burger, Y., Horev, C., Porat, A., Meir, A., and Cohen, R. (2004) Assessing the effect of genetic and anatomic variation of Cucurbita rootstocks on vigour, survival and yield of grafted melons. J. Hortic. Sci. Biotechnol. 79, 370-374.

Eis, S. (1972). Root grafts and their silvicultural implications. Can. J. For. Res. 2, 111-120. doi: 10.1139/x72-022

Epstein, A. H. (1978). Root graft transmission of tree pathogens. Ann. Rev. Phytopathol. 16, 181-192. doi: 10.1146/annurev.py.16.090178.001145

Erez, A., Ram, Y., and, Bar-Yosef, B. (1992). The effect of restricted root volume on the development, yield and dry matter partitioning in young fruiting peach trees. Acta Hortic. 322, 199-214.

Evans, D. A., Wetter, L. R., and Gamborg, O. L. (1980). Somatic hybrid plants of Nicotiana glauca and Nicotiana tabacum obtained by protoplast fusion. Physiol. Plant. 48, 225-230. doi: 10.1111/j.1399-3054.1980.tb03246.x

Fischer, F. G., Bazzigher, G., and Kobert, H. (1960). Kuenstlichhergestellte wurzelverwachsungen. Mitt. Schweiz Anst. forstl. Versuchw. 6, 15-32.

Flaishman, M. A., Loginovski, K., Golobowich, S., and Lev-Yadun, S. (2008). Arabidopsis thaliana as a model system for graft union development in homografts and heterografts. J. Plant Growth Regul. 27, 231-239. doi: 10.1007/s00344-0089050-y

Fossey, A. (2009). Epigenetics: beyond genes. South. For. 71, 121-124.

Frankel, R. (1956). Graft-induced transmission to progeny of cytoplasmic male sterility in petunia. Science 124, 684-685. doi: 10.1126/science.124.3224.684

Fuentes, I., Stegemann, S., Golczyk, H., Karcher, D., and Bock, R. (2014). Horizontal genome transfer as an asexulal path to the formation of new species. Nature 511, 232-235. doi: 10.1038/nature13291

Fulton, R. W. (1966). Mechanical transmission of viruses of woody plants. Annu. Rev. Phytopathol. 4, 79-98. doi: 10.1146/annurev.py.04.090166.000455

Garner, R. J. (2013). The Grafter's Handbook, 6th Edn. London: Octopus Publishing Group.

Goldschmidt, E. E. (2013). The evolution of fruit tree productivity: a review. Econ. Bot. 67, 51-62. doi: 10.1007/s12231-012-9219-y

Golecki, B., Schulz, A., Carstens-Behrens, U., and Kollman, R. (1998). Evidence for graft transmission of structural phloem proteins or their precursors in heterografts of Cucurbitaceae. Planta 206, 630-640. doi: 10.1007/s0042 50050441

Goren, R., Huberman, M., and Goldschmidt, E. E. (2004). Girdling: physiological and horticultural aspects. Hortic. Rev. 30, 1-36.

Guan, W., Zhao, X., Hassel, R., and Thies, J. (2012). Defense mechanisms involved in disease resistance of grafted vegetables. HortScience 47, 164-170.

Gur, A., Samish, R. M., and Lifshitz, E. (1968). The role of the cyanogenic glucoside of the quince in the incompatibility between pear cultivars and quince rootstocks. Hortic. Res. 8, 113-134.

Hadas, R., Ashulin, L., and Bar-Joseph, M. (1992). Transmission of a citrus viroid to avocado by heterologous grafting. Plant Dis. 76, 357-359. doi: 10.1094/PD76-0357

Hammond-Kosack, K. E., and Jones, J. D. G. (1997). Plant disease resistance genes. Annu. Rev. Plant Biol. 48, 575-607. doi: 10.1146/annurev.arplant.48.1.575

Harada, T. (2010). Grafting and RNA transport via phloem tissue in horticultural plants. Sci. Hortic. 125, 545-550. doi: 10.1016/j.scienta.2010.05.013

Hare, P. (2014). New plant species through grafting. Nat. Biotech. 32, 887. doi: $10.1038 /$ nbt. 3010

Haroldsen, V. M., Szczerba, M. W., Aktas, H., Lopez-Baltazar, J., Mar, J. O., ChiHam, C. L., et al. (2012). Mobility of transgenic nucleic acids and proteins within grafted rootstocks for agricultural improvement. Front. Plant Sci. 3:39. doi: 10.3389/fpls.2012.00039

Haywood, V., Yu, T. S., Huang, N. C., and Lucas, W. J. (2005). Phloem long-distance trafficking of Gibberellic-Acid-Insensitive RNA regulates leaf development. Plant J. 42, 49-68. doi: 10.1111/j.1365-313X.2005.02351.x

Huang, H., Norton, J. D., Boyhan, G. E., and Abrahams, B. R. (1994). Graft compatibility among chestnut (Castanea) species. J. Am. Soc. Hortic. Sci. 119, 1127-1132.

Ismail, M. R., and Davies, W. J. (1998). Root restriction affects leaf growth and stomatal response: the role of xylem sap ABA. Sci. Hortic. 74, 257-268. doi: $10.1016 /$ S0304-4238(98)00090-9 
Janick, J. (2005). The origins of fruits, fruit growing, and fruit breeding. Plant Breed. Rev. 25, 255-320.

Johkan, M., Mitukuri, K., Yamasaki, S., Mori, G., and Oda, M. (2009). Causes of defoliation and low survival rate of grafted sweet pepper plants. Sci. Hortic. 119, 103-107. doi: 10.1016/j.scienta.2008.07.015

Kaddoura, R. L., and Mantell, S. H. (1991). Synthesis and characterization of Nicotiana-Solanum graft chimeras. Ann. Bot. 68, 547-556.

Kalantidis, K., Schumacher, H. T., Alexiadis, T., and Helm, J. M. (2008). RNA silencing movement in plants. Biol. Cell 100, 13-26. doi: 10.1042/BC20070079

Kao, T. H., and Huang, S. (1994). Gametophytic self-incompatibility: a mechanism for self/nonself discrimination during sexual reproduction. Plant Physiol. 105, $461-466$.

Kawaguchi, M., Taji, A., Backhouse, D., and Oda, M. (2008). Anatomy and physiology of graft incompatibility in solanaceous plants. J. Hortic. Sci. Biotech. 83, $581-588$.

Kehr, J. (2013). Systemic regulation of mineral homeostasis by micro RNAs. Front. Plant Sci. 4:145. doi: 10.3389/fpls.00145

Kehr, J., and Buhtz, A. (2013). "Endogenous RNA constituents of the phloem and their possible roles in long-distance signaling," in Molecular Cell Biology, Systemic Communication, Biotic Interactions, eds G. A. Thompson and A. J. E. van Bel (Oxford: Phloem: Wiley-Blackwell Publishing), 186-208.

King, S. R., Davis, A. R., Liu, W., and Levi, A. (2008). Grafting for disease resistance. HortScience 43, 1673-1676.

Koepke, T., and Dhingra, A. (2013). Rootstock scion somatogenetic interactions in perennial composite plants. Plant Cell Rep. 32, 1321-1327. doi: 10.1007/s00299013-1471-9

Lang, A. (1965). "Physiology of flower initiation," in Encyclopedia of Plant Physiology, Vol. 15/1, ed. W. Ruhland (Berlin: Springer), 1380-1536.

LeBlanc, M., Kim, G., and Westwood, J. H. (2012). RNA trafficking in parasitic plant systems. Front. Plant Sci. 3:203. doi: 10.3389/fpls.2012.00203

Lee, J. M., and Oda, M. (2003). Grafting of herbaceous vegetable and ornamental crops. Hortic. Rev. 28, 61-124. doi: 10.1002/9780470650851.ch2

Lev-Yadun, S. (2011). Why should trees have natural root grafts. Tree Physiol. 31, 575-578. doi: 10.1093/treephys/tpr061

Li, C.-Y., Weiss, D., and Goldschmidt, E. E. (2003). Girdling affects carbohydraterelated gene expression in leaves, bark and roots of alternate-bearing citrus trees. Ann. Bot. 92, 137-143. doi: 10.1093/aob/mcg 108

Li, J., Wang, Y., Zhang, L., Liu, B., Cao, L., Qi, Z., et al. (2013). Heritable variation and small RNAs in the progeny of chimeras of Brassica juncae and Brassica oleraceae. J. Exp. Bot. 64, 4851-4862. doi: 10.1093/jxb/ert266

Lifshitz, E., Eviatar, T., Rozman, A., Shalit, A., Goldshmidt, A., Amsellem, Z., et al. (2006). The tomato FT ortholog triggers systemic signals that regulate growth and flowering and substitute for diverse environmental stimuli. Proc. Natl. Acad. Sci. U.S.A. 103, 6398-6403. doi: 10.1073/pnas.0601620103

Liu, Y.-S. (2006). Historical and modern genetics of plant graft hybridization. $A d v$. Genet. 56, 101-129. doi: 10.1016/S0065-2660(06)56003-1

Liu, Y.-S., Wang, Q.-L., and Li, B.-Y. (2010). New insights into plant graft hybridization. Heredity 104, 1-2. doi: 10.1038/hdy.2009.115

Lopes, S. A., Bertolini, E., Frare, G. F., Martins, E. C., Wulff, N. A., Teixiera, D. C., et al. (2009). Graft transmission efficiencies and multiplication of 'Candidatus Liberi bacter americanus' and 'Ca. Liberi bacter asiaticus' in citrus plants. Phytopathology 99, 301-306. doi: 10.1094/PHYTO-99-3-0301

Lough, T. J., and Lucas, W. J. (2006). Integrative plant biology: role of phloem long-distance trafficking. Annu. Rev. Plant Biol. 57, 203-232. doi: 10.1146/annurev.arplant.56.032604.144145

Louws, F. J., Rivard, C. L., and Kubota, C. (2010). Grafting fruiting vegetables to manage soilborne pathogens, foliar pathogens, arthropods and weeds. Sci. Hortic. 127, 127-146. doi: 10.1016/j.scienta.2010.09.023

Martinez-Ballesta, M. C., Alcaraz-Lopez, C., Muries, B., Mota-Cadenas, C., and Carvajal, M. (2010). Physiological aspects of rootstock scion interactions. Sci. Hortic. 127, 112-118. doi: 10.1016/j.scienta.2010.08.002

Melnyk, C. W., Molnar, A., and Baulcombe, D. C. (2011). Intercellular and systemic movement of RNA silencing signals. EMBO J. 30, 3553-3563. doi: 10.1038/emboj.2011.274

Menda, N., Eshed, Y., and Zamir, D. (2006). Reciprocal grafting of 61 randomly selected morphological tomato mutants reveal no evidence for systematically transmitted phenotypic alterations. Tomato Genet. Coop. 56, 29-32.

Michurin, I. V. (1949). Selected Works. (Moscow: Foreign Languages Publishing House).
Mikona, C., and Jelkmann, W. (2010). Replication of grapevine leafroll-associated virus-7 (GLRaV-7) by Cuscuta species and its transmission to herbaceous plants. Plant Dis. 94, 471-476. doi: 10.1094/PDIS-94-4-0471

Moing, A., Carbonne, F., and Gaudillere, J. P. (1990). Growth and carbon partitioning in compatible and incompatible peach/plum grafts. Physiol. Plant. 79, 540-546. doi: 10.1111/j.1399-3054.1990.tb02115.x

Moing, A., and Gaudillere, J. P. (1992). Carbon and nitrogen partitioning in peach/plum grafts. Tree Physiol. 10, 81-92. doi: 10.1093/treephys/10.1.81

Molnar, A., Melnyk, C. W., Bassett, A., Hardcastle, T. J., Dunn, R., and Baulcombe, D. C. (2010). Small silencing RNAs in plants are mobile and direct epigenetic modification in recipient cells. Science 328, 872-875. doi: 10.1126/science. 1187959

Moore, R. (1984). A model for graft compatibility-incompatibility in higher plants. Am. J. Bot. 71, 752-758. doi: 10.2307/2443372

Mosse, B. (1962). Graft Incompatibility in Fruit Trees: With Particular Reference to its Underlying Causes. Technical Communication No. 28. Kent: Commonwealth Agricultural Bureaux, 36.

Mudge, K., Janick, J., Scofield, S., and Goldschmidt, E. E. (2009). A history of grafting. Hortic. Rev. 35, 437-493. doi: 10.1002/9780470593776.ch9

Ohta, Y. (1991). Graft-transformation, the mechanism for graft-induced genetic changes in higher plants. Euphytica 55, 91-99. doi: 10.1007/BF00022565

Olmstead, M., Lang, N. S., Ewers, F. W., and Owens, S. A. (2006). Xylem vessel anatomy of sweet cherries grafted onto dwarfing and nondwarfing rootstocks. J. Am. Soc. Hortic. Sci. 131, 577-585.

Omid, A., Keilin, T., Glass, A., Leshkowitz, D., and Wolf, S. (2007). Characterization of phloem-sap transcription profile in melon plants. J. Exp. Bot. 58, 3645-3656. doi: $10.1093 / \mathrm{jxb} / \mathrm{erm} 214$

Palauqui, J. C., Elmayan, T., Polien, J. M., and Vaucheret, H. (1997). Systemic acquired silencing: transgene-specific post-transcriptional silencing is transmitted by grafting from silenced stocks to non-silenced scions. EMBO J. 16, 4738-4745. doi: 10.1093/emboj/16.15.4738

Park, S. W., Kaimoyo, E., Kumar, D., Mosher, S., and Klessig, D. F. (2008). Methyl salicylate is a critical mobile signal for plant systemic acquired resistance. Science 318, 113-116. doi: 10.1126/science.1147113

Paszkowski, J., and Grossniklaus, U. (2011). Selected aspects of transgenerational epigenetic inheritance and resetting in plants. Curr. Opin. Plant Biol. 14, 195-203. doi: 10.1016/j.pbi.2011.01.002

Pina, P., and Errea, P. (2005). A review of new advances in mechanism of graft compatibility-incompatibility. Sci. Hortic. 106, 1-11. doi: 10.1016/j.scienta. 2005.04.003

Poethig, R. S. (2009). Small RNAs and developmental timing in plants. Curr. Opin. Genet. Dev. 19, 374-378. doi: 10.1016/j.gde.2009.06.001

Rao, A. N. (1966). Developmental anatomy of natural root grafts in Ficus globosa. Aust. J. Bot. 14, 269-276. doi: 10.1071/BT9660269

Rapp, R. A., and Wendel, J. F. (2005). Epigenetics and plant evolution. New Phytol. 168, 81-91. doi: 10.1111/j.1469-8137.2005.01491.x

Ross-Ibarra, J., Morell, P. L., and Gaut, B. S. (2007). Plant domestication, a unique opportunity to identify the genetic basis of adaptation. Proc. Natl. Acad. Sci. U.S.A. 104, 8641-8648. doi: 10.1073/pnas.0700643104

Schilmiller, A. L., and Howe, G. A. (2005). Systemic signaling in wound response. Curr. Opin. Plant Biol. 8, 369-377. doi: 10.1016/j.pbi.2005.05.008

Schöning, U., and Kollmann, R. (1997). Phloem translocation in regenerating in vitro heterografts of different compatibility. J. Exp. Bot. 48, 289-295. doi: 10.1093/jxb/48.2.289

Shepard, J. F., Bidney, D., Barsby, T., and Kemble, R. (1983). Genetic transfer in plants through interspecific protoplast fusion. Science 219, 683-688. doi: $10.1126 /$ science. 219.4585 .683

Soumelidou, K., Battey, N. H., John, P., and Barnett, J. R. (1994). The anatomy of the developing bud union and its relationship to dwarfing in apple. Ann. Bot. 74, 605-611. doi: 10.1006/anbo.1994.1161

Spiegelman, Z., Golan, G., and Wolf, S. (2013). Don't kill the messenger: long-distance trafficking of mRNA molecules. Plant Sci. 213, 1-8. doi: 10.1016/j.plantsci.2013.08.011

Stegemann, S., and Bock, R. (2009). Exchange of genetic material between cells in plant tissue grafts. Science 324, 649-651. doi: 10.1126/science.1170397

Stegemann, S., Keuthe, M., Greiner, S., and Bock, R. (2012). Horizontal transfer of chloroplast genomes between plant species. Proc. Natl. Acad. Sci. U.S.A. 109, 2434-2438. doi: 10.1073/pnas.1114076109 
Stubbe, H. (1954). Uber die vegetative hybridisierung von pflanzen. Versuch an Tomate Mutanten. Kulturepflanze 2, 185-236. doi: 10.1007/BF02095736

Swingle, C. F. (1927). Graft hybrids in plants. J. Heredity 18, 73-94.

Takayama, S., and Isogai, A. (2005). Self-incompatibility in plants. Annu. Rev. Plant Biol. 56, 467-489. doi: 10.1146/annurev.arplant.56.032604.144249

Takeda, S., and Paszkowski, J. (2006). DNA methylation and epigenetic inheritance during plant gametogenesis. Chromosoma 115, 27-35. doi: 10.1007/s00412-0050031-7

Taller, J., Hirata, Y., Yagishita, N., Kita, M., and Ogata, S. (1998). Graft-induced genetic changes and the inheritance of several characteristics in pepper (Capsicum annuum L.). Theor. Appl. Genet. 97, 705-713. doi: 10.1007/s001220050946

Thrall, P. H., Bever, J. D., and Burdon, J. J. (2010). Evolutionary change in agriculture: the past, present and future. Evol. Appl. 3, 405-408. doi: 10.1111/j.1752-4571.2010.00155.x

Topoleski, L. D., and Janick, J. (1963). A study of graft-induced alterations in eggplant. Proc. Am. Soc. Hortic. Sci. 83, 559-570.

Tsaballa, A., Athanasiadis, C., Pasentsis, K., Ganopoulos, I., Nianiou-Obeidat, I., and Tsafaris, A. (2013). Molecular studies of inheritable induced changes in pepper (Capsicum annuum) fruit shape. Sci. Hortic. 149, 2-8. doi: 10.1016/j.scienta.2012.06.018

Turnbull, C. G. N. (2010). Grafting as a research tool. Methods Mol. Biol. 655, 11-26. doi: 10.1007/978-1-60761-765-5_2

Turnbull, C. G. N., Booker, J. P., and Leyser, H. M. O. (2002). Micrografting techniques for testing long-distance signaling in Arabidopsis. Plant J. 32, 255-262. doi: 10.1046/j.1365-313X.2002.01419.x

Tuttle, M. A., and Gotlieb, A. R. (1985). Graft union histology and distribution of tomato ringspot virus in infected McIntosh/Malling Merton 106 apple trees. Phytopathology 75, 347-351. doi: 10.1094/Phyto75-347

Tzarfati, R., Ben-Dor, S., Sela, I., and Goldschmidt, E. E. (2013). Graft-induced changes in microRNA expression patterns in Citrus leaf petioles. Open Plant Sci. J. 7, 17-23. doi: 10.2174/1874294701307010017

Ueki, S., and Citovski, V. (2005). Control improves with age: intercellular transport in plant embryos and adults. Proc. Natl. Acad. Sci. U.S.A. 102, 1817-1818. doi: 10.1073/pnas.0409785102

Wang, J. W., Park, M. Y., Wang, L. J., Koo, Y., Chen, X. Y., Weigel, D., et al. (2011). MiRNA control of vegetative phase change in trees. PLoS Genet. 7:e1002012. doi: 10.1371/journal.pgen.1002012

Wang, Y.-Q. (2011). Plant grafting and its application in biological research. Chinese Sci. Bull. 56, 3511-3517. doi: 10.1007/s11434-011-4816-1

Wareing, P. F. (1959). Problems of juvenility and flowering in trees. J. Linn. Soc. Lond. (Bot.) 56, 282-289. doi: 10.1111/j.1095-8339.1959.tb02504.x
Webber, H. J. (1948). "Rootstocks: their character and reactions," in The Citrus Industry, Vol. 2, eds L. D. Batchelor and H. J. Webber (Berkeley, CA: University of California Press), 69-168.

Webster, T. (2002). Dwarfing rootstocks: past, present and future. Compact Fruit Tree 35, 67-72.

Wu, R., Wang, X., Lin, Y., Ma, Y., Liu, G., Yu, X., et al. (2013). Inter-species grafting caused extensive and heritable alterations of DNA methylation in Solanaceae plants. PLoS ONE 8:e61995. doi: 10.1371/journal.pone.0061995

Wutscher, H. K. (1979). Citrus rootstocks. Hortic. Rev. 1, 237-269.

$\mathrm{Xu}$, C., Tian, J., and Mo, B. (2013a). siRNA-mediated DNA methylation and H3K9 dimethylation in plants. Protein Cell 4, 656-663. doi: 10.1007/s13238-0133052-7

$\mathrm{Xu}, \mathrm{H}$., Iwashiro, R., Li, T., and Harada, T. (2013b). Long-distance transport of Gibberellic Insensitive mRNA in Nicotiana benthamiana. BMC Plant Biol. 13:165. doi: 10.1186/1471-2229-13-165

Yin, H., Yan, B., Sun, J., Jia, P., Zhang, Z., Yan, X., et al. (2012). Graft-union development: a delicate process that involves cell-cell communication between scion and stock for local auxin accumulation. J. Exp. Bot. 63, 4219-4232. doi: 10.1093/jxb/ers109

Zeevaart, J. A. D. (2006). Florigen coming of age after 70 years. Plant Cell 18, 1783-1789. doi: 10.1105/tpc.106.043513

Zeevaart, J. A. D. (2008). Leaf-produced floral signals. Curr. Opin. Plant Biol. 11, 541-547. doi: 10.1016/j.pbi.2008.06.009

Zhou, X. M., Liu, Y. S., and Li, X. J. (2013). Confirmation of a purple-leaved plum graft hybrid. Genet. Mol. Res. 12, 710-713. doi: 10.4238/2013.March.11.19

Conflict of Interest Statement: The author declares that the research was conducted in the absence of any commercial or financial relationships that could be construed as a potential conflict of interest.

Received: 14 July 2014; accepted: 01 December 2014; published online: 17 December 2014.

Citation: Goldschmidt EE (2014) Plant grafting: new mechanisms, evolutionary implications. Front. Plant Sci. 5:727. doi: 10.3389/fpls.2014.00727

This article was submitted to Plant Physiology, a section of the journal Frontiers in Plant Science.

Copyright (c) 2014 Goldschmidt. This is an open-access article distributed under the terms of the Creative Commons Attribution License (CC BY). The use, distribution or reproduction in other forums is permitted, provided the original author(s) or licensor are credited and that the original publication in this journal is cited, in accordance with accepted academic practice. No use, distribution or reproduction is permitted which does not comply with these terms. 